\title{
Nonchemical control of a perennial weed, Cirsium arvense, in arable cropping systems. A review
}

\author{
Elise Favrelière $^{1}$ - Aïcha Ronceux ${ }^{1}$ - Jérôme Pernel ${ }^{1}$ • Jean-Marc Meynard ${ }^{2}$
}

Accepted: 21 July 2020 / Published online: 7 August 2020

(C) INRAE and Springer-Verlag France SAS, part of Springer Nature 2020

\begin{abstract}
Cirsium arvense (L.) Scop. is one of the most problematic perennial weeds in European countries, causing notable yield losses in both conventional and organic arable cropping systems. C. arvense control is essential because its infestation spreads rapidly and has negative impacts for several years due to its biological characteristics. Herbicidal treatments are the main control methods used in conventional input-based systems, but they are not always more effective than cultural practices. However, the cultural practices currently employed in arable cropping systems are often expensive and time-consuming. To guarantee the efficiency of these control practices, knowledge of $C$. arvense biology is essential. This review synthesizes the key points from the previous literature on $C$. arvense biology that can be mobilized to this end and analyzes the literature on different strategies of $C$. arvense control without herbicides. These strategies are (1) limitation of $C$. arvense dispersal, (2) weakening of root reserves, (3) extraction of roots, (4) competition with cultivated species, and (5) physical destruction. There is also a review of reported experiences using these strategies for $C$. arvense control, and relevant information is presented on associated biological processes to optimize the efficacy of each practice. The benefits and drawbacks of these strategies for $C$. arvense control are also emphasized, as well as the possibility of combining them in cropping systems, even though some knowledge gaps remain. This review confirms that one individual practice, implemented in 1 year only, is not sufficient to provide satisfactory, long-term control of $C$. arvense; therefore, further studies on combinations of control strategies and processes are required. There is a particular lack of knowledge about the duration of the effect of $C$. arvense control strategies.
\end{abstract}

Keywords Cirsium arvense $\cdot$ Perennial weed $\cdot$ Weed control $\cdot$ Nonchemical methods $\cdot$ Arable cropping systems

\section{Contents}

1. Introduction

2. C. arvense biology and implications for its control

2.1 Perennial weed characteristics: the importance of the knowledge of their biology in their control

2.2 Biological particularities of $C$. arvense

2.2.1 Development cycle of $C$. arvense and the importance of vegetative propagation

2.2.2 Dynamics of $C$. arvense root reserves during the year

3. Nonchemical control methods of $C$. arvense based on biological processes

Elise Favrelière

e.favreliere@hotmail.fr

1 Agro-Transfert Ressources et Territoires, F-80200 Estrées-Mons, France

2 UMR SAD-APT, INRA, F-75231 Paris Cedex 5, France
3.1 Limitation of $C$. arvense dispersal

3.1.1 Limitation of seed dispersal

3.1.2 Limitation of root fragment dispersion

3.2 Use of mechanical interventions to weaken the root reserves of $C$. arvense

3.2.1 Principles of weakening root reserves

3.2.2 Mowing and hoeing

3.2.3 Stubble cultivation

3.2.4 Plowing

3.3 Effect of competition with cultivated species

3.3.1 Principles of competition for $C$. arvense control

3.3.2 Competitive pluriannual crops: alfalfa and temporary grasslands

3.3.3 Competitive annual crops and cover crops to control C. arvense

3.4 Effect of root extraction on $C$. arvense

3.4.1 Principles of root extraction 
3.4.2 Methods using root extraction for $C$. arvense control

3.5 Other methods to control C. arvense

\subsubsection{Solarization}

3.5.2 Biological control

3.6 Combination of control practices impacting different biological processes

4. Discussion

5. Conclusions

References

\section{Introduction}

Most problematic weeds in arable cropping systems in Europe are perennial weeds (Glemnitz et al. 2007). C. arvense (L.) Scop. (thistle) is considered problematic in both conventional (Schroeder et al. 1993) and organic cropping systems (Riesinger and Hyvönen 2006; Glemnitz et al. 2007) in the northern hemisphere, including all European countries, Asia, Canada, and the northern USA. In the Southern Hemisphere, C. arvense has become an issue in Australia, New Zealand, South America, and South Africa. C. arvense is recorded as an injurious weed in the official list of plant pests, and its control is made obligatory in various countries, in Europe and in North America, New Zealand, and Australia (Tiley 2010). $C$. arvense can cause $30-50 \%$ yield losses in arable crops, with a density of 15-20 C. arvense shoots per $\mathrm{m}^{-2}$ (O'Sullivan et al. 1982, 1985; Patriquin et al. 1986). Studies show that yield losses increase linearly beyond ten $C$. arvense shoots per $\mathrm{m}^{-2}$ (O'Sullivan et al. 1982, 1985) and can reach $70 \%$ in some situations (Tiley 2010). This can be due in part to allelopathic effects, especially in winter wheat (Evans 1984; Pilipavičius and Romaneckas 2014) and legume crops (Fig. 1) (Golubinova and Ilieva 2015)

C. arvense infestation also involves costly management practices, such as high herbicide rates, numerous cultural practices, or manual interventions. In conventional inputbased farming systems, chemical weeding is the primary practice in the control of $C$. arvense, with glyphosate as one of the main herbicides used. In modern agriculture (conventional or organic), weed control should be based on the combination of various control methods: longer rotations, soil tillage, mowing, and manual or mechanical weeding, with the chemical solution being the last resort (Buhler et al. 2000; Liebman et al. 2009; Westwood et al. 2018). It has also been shown that chemical control is not always more effective than cultural practices (Tavaziva 2017; Davis et al. 2018). In organic farming, $C$. arvense control is mainly based on the presence of grasslands in the rotation and consequently is more complicated on farms without livestock (Melander et al. 2016). $C$. arvense control is especially important because the infestation is likely to spread rapidly and has a negative impact lasting several years if effective management is not undertaken. For
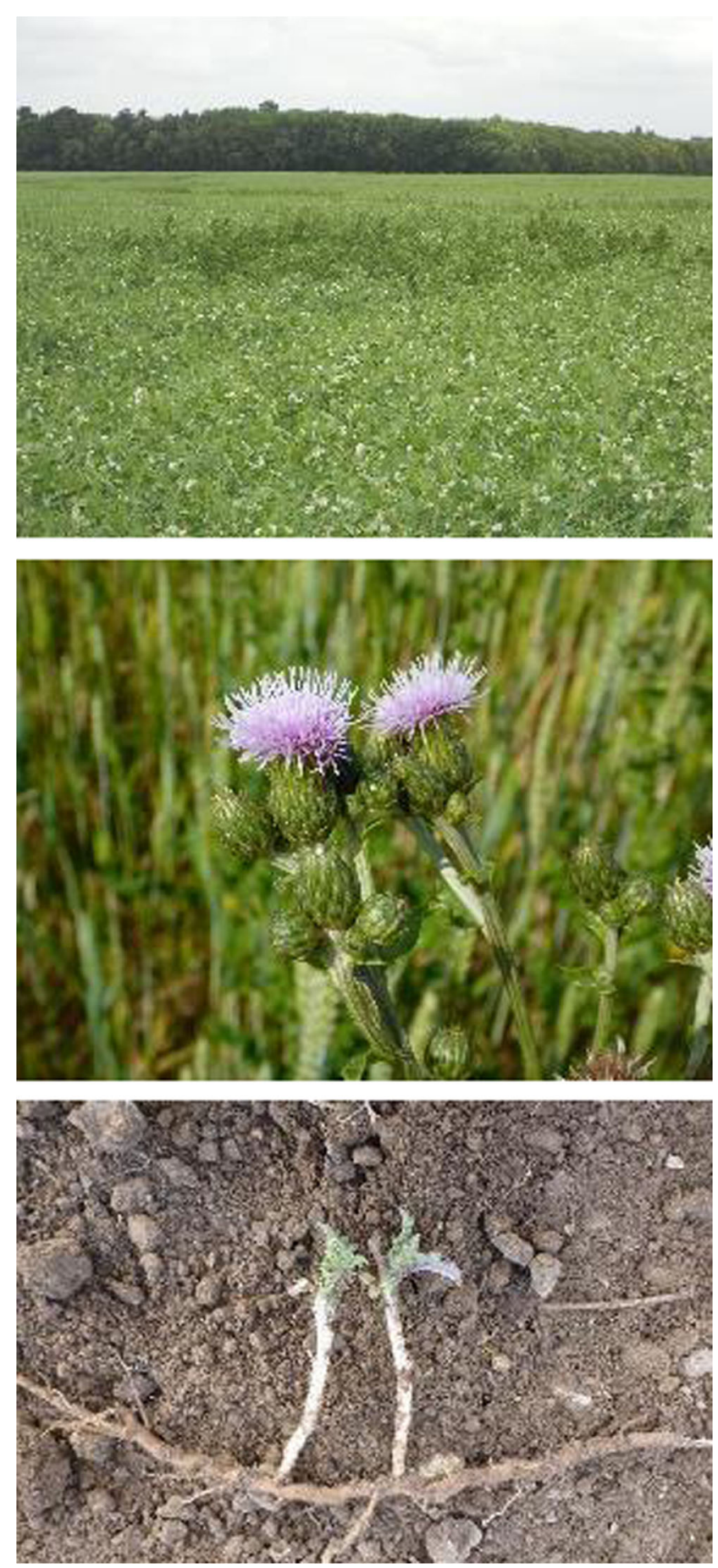

Fig. 1 Overview of the development of a C. arvense patch in a spring pea (Pisum sativum) field (a), achieved by sexual reproduction through flowering and seed production (b) and vegetative multiplication through the development of new aerial shoots from axillary buds on a creeping horizontal root (c). (C) E. Favrelière, Agro-Transfert Ressources et Territoires)

these reasons, there is a need for studies on alternative control methods of $C$. arvense to minimize the use of herbicides.

This review describes existing methods of nonchemical control of $C$. arvense in connection with biological processes 
involved in its development. The side effects of these practices are discussed, and the lack of knowledge is highlighted.

\section{C. arvense biology and implications for its control}

\subsection{Perennial weed characteristics: the importance of the knowledge of their biology in their control}

Perennial weeds are characterized by their capacity to spread both by seed production, such as annual weeds, and by vegetative propagation (Håkansson 2003). Vegetative propagation is facilitated by specific root structures (rhizomes, stolons, creeping roots, etc.) that allow perennial weeds to store nutritive elements and remain alive for several years (Rogers 1928; Håkansson 2003). Vegetative propagation occurs spontaneously by clone development from vegetative buds located on root structures. Most of the buds are maintained in paradormancy through apical dominance (Borochov et al. 1997).

Vegetative propagation can also be induced by root structure fragmentation caused by cropping practices (cultivation, tillage, etc.). Root structure fragmentation leads to the end of apical dominance and enables new clones to be produced. This phenomenon is called regeneration ability (Håkansson 1982, 2003; Dock Gustavsson 1997). Due to vegetative propagation, mechanical weeding, as practiced on annual weeds, is not effective in the control of perennial weeds (Melander et al. 2012)

\subsection{Biological particularities of $C$. arvense}

\subsubsection{Development cycle of $C$. arvense and the importance of vegetative propagation}

C. arvense is a dioecious plant belonging to the Asteraceae family, requiring mating between male and female flowers (Hodgson 1968; Lalonde and Roitberg 1994). Seeds are generally produced by the female flowers, but some cases of low seed production by male flowers have been reported (Heimann and Cussans 1996). C. arvense plants developed from one seed are not able to produce seeds if they are isolated in a field (Sagar and Rawson 1964; Heimann and Cussans 1996).

Seed production by $C$. arvense is generally reported to be sizeable (Rogers 1928; Gruber and Claupein 2009), but Donald (1990) observed that it can be limited. This difference can be linked to phenotypic plasticity among $C$. arvense populations (Heimann and Cussans 1996). Seed quantity can vary with the sex ratio (Lalonde and Roitberg 1994; Heimann and Cussans 1996). As most of the seeds are able to germinate immediately (Hodgson 1968; Heimann and Cussans 1996), the development of new patches in a field through seeds would be a usual phenomenon (Hettwer and Gerowitt 2004), even if seedling establishment is slow due to their low competitiveness compared with that of other species (Heimann and Cussans 1996). Sexual reproduction is important for $C$. arvense genetic diversity (Heimann and Cussans 1996; Tiley 2010), which favors its adaptation to environmental conditions and its competitive ability (Nadeau and Vanden Born 1989; Bommarco et al. 2010; Nobarinezhad et al. 2020). Seed production also allows the introduction of $C$. arvense in new spaces through the light plumes attached to the achenes, which allow seeds to be transported by the wind (Moore 1975; Tiley 2010). However, a small number of seeds can travel a substantial distance, with $9.9 \%$ and $0.2 \%$ of the plumes still attached to an achene at distances of $10 \mathrm{~m}$ and $1 \mathrm{~km}$, respectively (Bakker 1960; Tiley 2010). $C$. arvense spread in a field is mainly due to vegetative propagation (see Fig. 1) (Heimann and Cussans 1996; Tiley 2010). Plants coming from rhizome fragments grow faster than those developing from seeds (Strobach et al. 2008 in Tiley 2010).

Vegetative propagation is possible because of specific organs that permit $C$. arvense expansion and the storage of nutritive resources. $C$. arvense has deep vertical roots, mainly located below the top $20 \mathrm{~cm}$ of the soil (Nadeau and Vanden Born 1989) that have been found as deep as $6.75 \mathrm{~m}$ (Rogers 1928), and creeping horizontal roots that present axillary buds able to develop new aerial shoots (Fig. 1) (McAllister and Haderlie 1985; Tiley 2010). Aerial shoots can develop from any part of the horizontal roots (Tiley 2010). Nutritive resources are stored in both the horizontal and vertical roots (Rogers 1928) but preferentially in the vertical roots (McAllister and Haderlie 1985).

C. arvense seedlings are able to form new plants from root fragments from the two-leaf stage of $C$. arvense (Wilson 1979). This regeneration ability permits the survival and production of new $C$. arvense shoots even if aerial parts are cut (Håkansson 1982). Root fragments of $C$. arvense can produce new plants from a size of $10 \mathrm{~mm}$ (Hamdoun 1972) or even 3 $6 \mathrm{~mm}$ (Hayden 1934), possibly depending on genetic differences between populations. The depth of burial has little influence on regeneration ability since root fragments are able to regenerate at a depth of $1.80 \mathrm{~m}$ (Nadeau and Vanden Born 1989; Thomsen et al. 2014).

\subsubsection{Dynamics of $C$. arvense root reserves during the year}

To control perennial weeds, knowledge of the storage process of carbohydrates is necessary (Rodriguez et al. 2007; Nkurunziza and Streibig 2011) because it influences the optimum period for interventions (Brandsæter et al. 2010; Nkurunziza and Streibig 2011). 


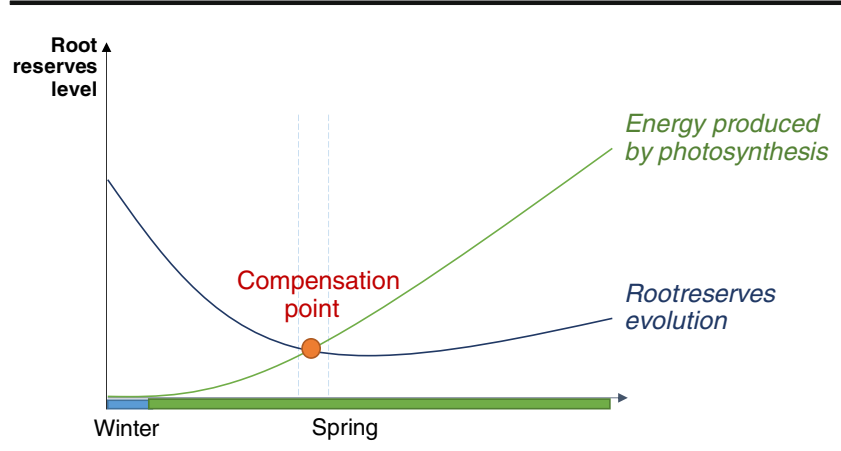

Fig. 2 Compensation point. The compensation point is reached when the energy produced by photosynthesis becomes sufficient to fulfill plant requirements for respiration and shoot growth. After this stage, $C$. arvense plants develop without mobilizing root reserves

In early spring, $C$. arvense uses carbohydrates stored in its root reserves as an energy source to produce new aerial shoots (McAllister and Haderlie 1985). After several weeks of growth, photoassimilation by aerial shoots becomes sufficient to fulfill plant requirements for respiration and shoot growth. This stage is called the compensation point (Fig. 2) (Håkansson 2003; Nkurunziza and Streibig 2011). It is important to know the compensation point because $C$. arvense root reserves are low at this stage and immediately afterwards. Once $C$. arvense reaches the compensation point, carbohydrate availability increases due to photosynthesis, and $C$. arvense shoot development accelerates (Håkansson 2003).

The compensation point of $C$. arvense is reached between the three-leaf and ten-leaf stages: the seven-to-ten-leaf stage has been identified by Dock Gustavsson (1997), the four-toseven-leaf stage by Håkansson (2003), the eight-leaf stage by Nkurunziza and Streibig (2011), and the three-to-four-leaf stage by Verwijst et al. (2018). This stage could vary with numerous factors, particularly with root fragment size: longer and heavier root fragments can regrow earlier and faster (Dock Gustavsson 1997; Verwijst et al. 2018). The time necessary to reach the compensation point is also influenced by the root burial depth (Dock Gustavsson 1997).

The use of root reserves is required again later in the spring to allow flowering and seed production (Bakker 1960; Hodgson 1968). Carbohydrates in the rhizome are at their lowest levels with the appearance of flower buds (Hodgson 1968; Moore 1975; Tworkoski 1992; Rodriguez et al. 2007). After this stage, C. arvense starts to gradually refill its root reserves (Welton et al. 1929). Photoassimilate migration to the roots is stimulated by shorter photoperiods and a decrease in temperature (Otzen and Koridon 1970; Tworkoski 1992; Nkurunziza and Streibig 2011). Stored carbohydrates reach a maximum in late summer/early fall (McAllister and Haderlie 1985). C. arvense then enters dormancy as a result of low temperatures (Tworkoski 1992; Nkurunziza and Streibig 2011). Figure 3, which has been created for this review, summarizes all the data on the evolution of $C$. arvense root reserves during the year.
Photosynthesis by $C$. arvense ceases during winter dormancy (Otzen and Koridon 1970; Nkurunziza 2010). However, the existence of winter dormancy has been contested since a minor effect of a decrease in temperature has sometimes been observed with a decreasing photoperiod (Liew et al. 2012), and root bud activity has been shown in late fall and winter (McAllister and Haderlie 1985). The reserves accumulated during this period determine the level of reserves available in late winter for the development of new shoots. The level of carbohydrates stored in the roots could fluctuate with annual climatic variations (Otzen and Koridon 1970). As a consequence of seasonal variations in $C$. arvense root reserves, $C$. arvense control is more efficient during early spring and after the start of flowering when root reserves are low (Welton et al. 1929).

\section{Nonchemical control methods of $C$. arvense based on biological processes}

\subsection{Limitation of C. arvense dispersal}

\subsubsection{Limitation of seed dispersal}

Seed dispersal is able to introduce $C$. arvense to new places and promote the genetic adaptation of $C$. arvense populations (Heimann and Cussans 1996), making the limitation of seed dispersal essential.

One method is the manual cutting of $C$. arvense inflorescences (Rogers 1928; Tiley 2010). Mechanical cutting of inflorescences can also be performed with a weed cutter if $C$. arvense plants are taller than the crop (Bond and Grundy 2001). This method allows $C$. arvense propagation in a contaminated field to be limited. However, the contribution of field-margin populations to $C$. arvense field invasion is small (Blumenthal and Jordan 2001).

It is also important to clean the threshing machine because weed seeds can be dispersed over great distances to adjacent harvested fields (Detmers 1927; Rogers 1928; Donald 1990). As home-saved crop seeds can be contaminated with $C$. arvense, certified or sorted crop seeds are used for a long time to limit its propagation (Rogers 1928; Hodgson 1968; Bond and Grundy 2001).

As weed seeds can also be present in forage, seeds ingested by cattle can be introduced to fields through manure (Rogers 1928). A few seeds of $C$. arvense are resistant to ingestion by horses, cows (0.5\%), and goats (5\%) (Detmers 1927; Tiley 2010). Composting manures can limit the germination capacity of seeds, but the compost process efficacy depends on its management: the fermentation period has to be at least 1 week long with temperatures maintained at $60{ }^{\circ} \mathrm{C}$ throughout the compost (Christoffoleti et al. 2007). 


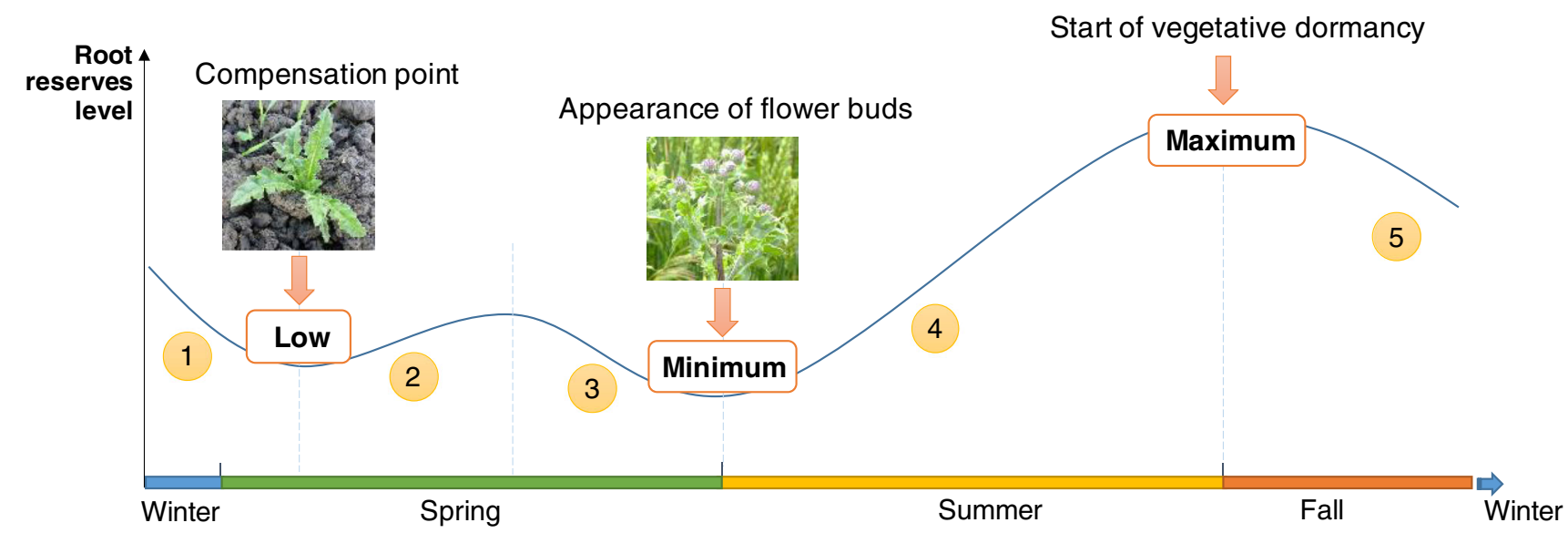

Low Key level of root reserves

\section{Biological processes:}

1 Use of root reserves to produce new aerial shoots

2 Reconstitution of root reserves due to photosynthesis produced by new shoots

3 Use of root reserves to allow seed production

4 Reconstitution of root reserves stimulated by low temperatures and the start of vegetative dormancy

5 Vegetative dormancy: no photosynthetic activity

Fig. 3 Conceptual model of the evolution of root reserves of C. arvense during the year. In early spring, root reserves decrease until $C$. arvense plants reach the compensation point. $C$. arvense plants then become selfsufficient through photoassimilation of aerial shoots. Later in the spring,

\subsubsection{Limitation of root fragment dispersion}

Creeping root fragments of $C$. arvense can remain stuck to the wheels of farm machinery or to tools, which can introduce the root fragments to other fields (Bond and Grundy 2001). Christoffoleti et al. (2007) underline the importance of cleaning machinery after use in contaminated fields.

\subsection{Use of mechanical interventions to weaken the root reserves of $C$. arvense}

\subsubsection{Principles of weakening root reserves}

To gradually weaken root reserves and limit the regrowth capacity of $C$. arvense, the aerial parts of $C$. arvense can be repeatedly destroyed. After each destruction, $C$. arvense shoots use the carbohydrates located in the root reserves to initiate shoot regrowth and photosynthesis activity. To achieve efficient control of $C$. arvense, destruction of aerial parts must be carried out every 500-600 degree days (Nkurunziza and Streibig 2011). It is important to schedule root reserves decrease again to allow seed production. From the appearance of $C$. arvense flower buds, root reserves start to increase greatly to reach a maximum regeneration of $C$. arvense root reserves before the start of vegetative dormancy

the period between two interventions in accordance with the stage of $C$. arvense at the compensation point (see Fig. 3). The goal is to allow $C$. arvense regrowth and carbohydrate use but to not allow root reserves to build up again (Liebman 2001; Andersson et al. 2013).

Various cultural practices can be used to achieve $C$. arvense exhaustion. Aerial parts can be destroyed by repeated mowing or hoeing. To increase weakening efficacy, repeated cultivations can also be performed. Cultivations induce root fragmentation, which produces a break in apical dormancy and new sprouting from every root fragment with a minimum size of 3-10 mm (see Section 2.2). Carbohydrates are used for each shoot regrowth, so the more roots that are fragmented, the more carbohydrates are used. To ensure the efficacy of the control method using cultivations, root fragments and new shoots must be destroyed by following cultivation or desiccation. Otherwise, this can lead to a high multiplication of $C$. arvense.

These practices can be implemented at different times of the year - in spring when root reserves are low or in late summer when large quantities of photoassimilates are transported 
to root reserves - but these practices are more efficient when root reserves are low.

\subsubsection{Mowing and hoeing}

Repeated mowing and hoeing are known to stimulate the regrowth of aerial parts (Graglia et al. 2006; Brandsæter et al. 2012). Selective mowing was tested in recent studies at the eight-to-ten-leaf stage (Verwijst et al. 2017) and ten-leaf stage (Tavaziva et al. 2019) of $C$. arvense, in which significant decreases of $60 \%$ and $88 \%$ in C. arvense density, respectively, were achieved with this practice. Significant decreases have also been observed in seed production (Verwijst et al. 2018), aboveground dry weight and dry weight per shoot (Tavaziva et al. 2019). However, most of the time, repeated mowing is not sufficient to control $C$. arvense on its own. Six mowings of a barley crop, performed at the three-to-six-leaf stage of $C$. arvense for 3 years, achieved a nonsignificant decrease in $C$. arvense biomass (Graglia et al. 2006). In contrast, repeated mowing of competitive crops, such as alfalfa, is effective (see Section 3.3). A slight but significant added effect of planting a cover crop in addition to repeated mowing has been observed, resulting in a $69 \%$ decrease in C. arvense aerial biomass (Graglia et al. 2006). Cripps et al. (2020) observed a genetic variation in tolerance to defoliation, with overcompensation of some genotypes by the increase in shoot biomass, shoot density, or height. This could explain the low efficiency sometimes observed for repeated mowing.

Stimulation of the regrowth of aerial parts can also be achieved by repeated hoeing. Only a few studies have tested this practice to control $C$. arvense. A nonsignificant decrease of $73 \%$ and $43 \%$ in $C$. arvense biomass has been observed after five and six successive hoeings, respectively, performed during the spring in barley grown at $24 \mathrm{~cm}$ row spacing (Graglia et al. 2006). In another trial, three successive hoeings were found to induce a nonsignificant reduction in root reserve level (Rodriguez et al. 2007). The limited impact on root reserves could explain the weak and short-term control provided by repeated hoeing.

Destruction of aerial parts seems to allow only limited control of $C$. arvense. Nonetheless, this practice could be mobilized in a global control strategy, combining several practices using various biological processes.

\subsubsection{Stubble cultivation}

Repeated stubble cultivation is a well-known control method that has been studied for many years. Root fragmentation in late summer is a major practice used to control $C$. arvense because this can be undertaken after the cereal harvest, even though the optimal intervention period is in late spring (Hodgson 1958; Derscheid et al. 1961). A minimum of three cultivations should be implemented to achieve satisfactory efficacy (Lukashyk et al. 2007; Brandsæter et al. 2012). The most commonly used implement is the duckfoot cultivator (Verschwele and Häusler 2004). Recent studies have compared implements, for example, with some strategies, including the moldboard plow or S-tine harrow. The results of known studies are presented in Table 1.

The most important factors in controlling $C$. arvense appear to be the number and timing of the stubble cultivations. Numerous cultivations carried out from late spring to late summer, which is one type of "bare fallow" practice, can suppress $C$. arvense in 1 or 2 years (Derscheid et al. 1961; Hodgson 1970; Thomsen et al. 2015). This practice is not easy to carry out because it is an expensive method: a year without crops is required, and the numerous cultivations involve large fuel consumption and extensive working time (Melander et al. 2016). This can explain why this practice is mainly used in old experimental trials. In the only recent trial, which tested bare fallow conditions with repeated cultivations, a PTO-driven rotary cultivator was used to shorten the bare fallow duration (see Section 3.4) (Lötjönen 2017).

Cultivations implemented later in the summer, after the harvest of arable crops, can also provide significant control of $C$. arvense, with three to four cultivations during two consecutive intercrops. With 2-3 cultivations, Melander et al. (2012) observed lower reductions in $C$. arvense densities (see Table 1).

Various implements have been tested, but few differences in the outcomes have been observed. This could be because all the implements tested are effective because previous experiments have provided knowledge about the conditions required for the implements to be efficient (Cox 1913; Detmers 1927). A cultivation depth of between 5 and $15 \mathrm{~cm}$ also seems to make little difference on $C$. arvense control (see Table 1) (Melander et al. 2012; Thomsen et al. 2014). However, the increase in the depth of stubble cultivations could cause annual weed seeds to rise to the soil surface. For that reason, cultivation depth has to be chosen depending on the usual tillage depth of farmers: the cultivation depth can be the same or less than the usual tillage depth, even if tillage is made at a low depth (i.e., 4-5 cm).

Soil type can affect the distribution and diameter of $C$. arvense roots, as reported by Rogers (1928). Cultivations are more effective in sandy and light soils (Brandsæter et al. 2017) because most of the roots here are located in the upper soil layers. The roots are also thinner in these soils, which means that less carbohydrate is stored (Rogers 1928).

Another possible factor in the variation is the ecotype of $C$. arvense. Efficacy differences between several ecotypes have been observed by Hodgson (1970). Most $C$. arvense patches were suppressed after one season with intensive cultivations, but some patches were still present with a density of $32 \%$ of their initial density. To build a sustainable cropping system with lasting control of $C$. arvense, greater knowledge about 


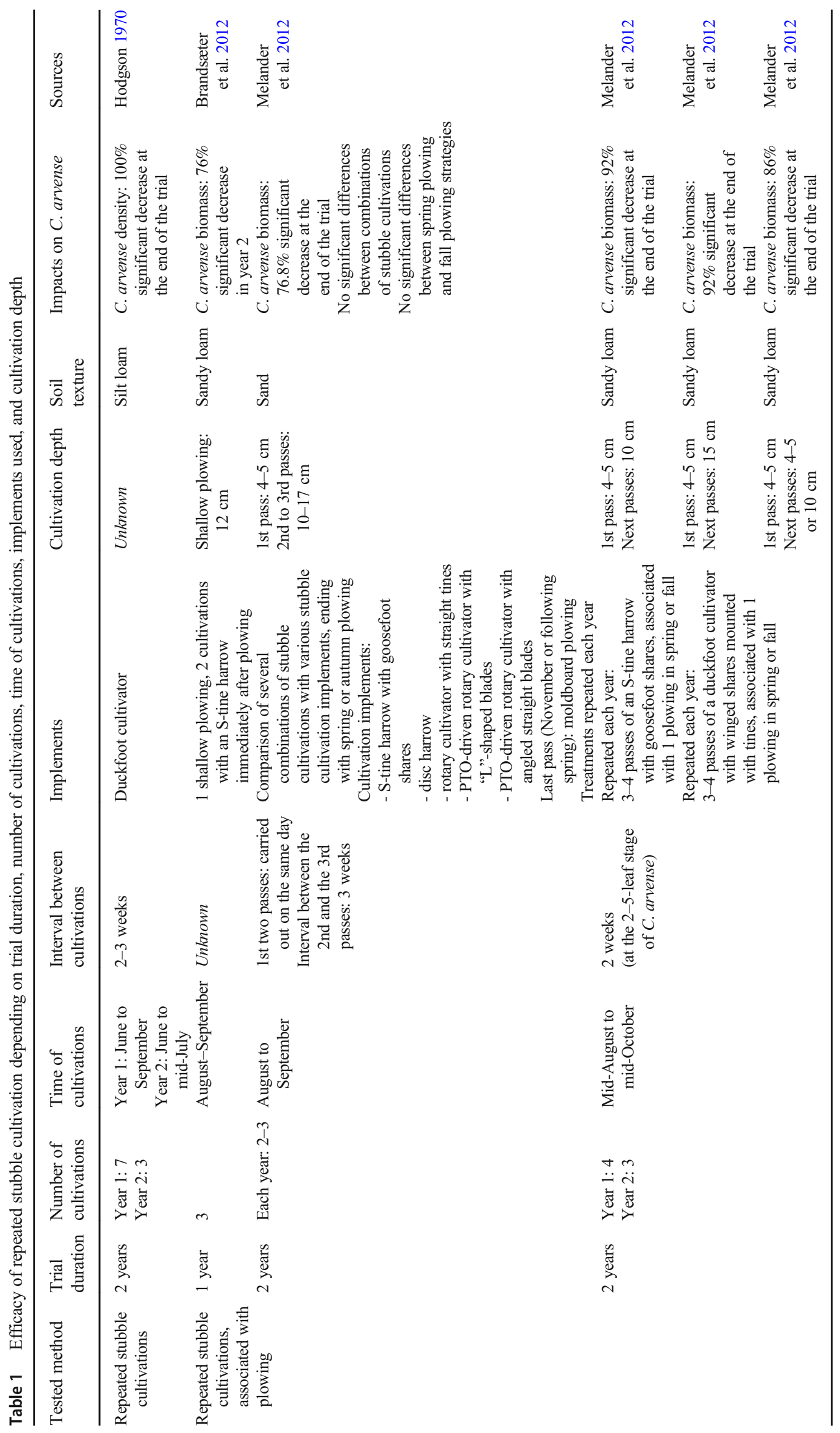

INRAC $\underline{\text { Springer }}$ 
variations in efficacy between $C$. arvense ecotypes and the duration of the beneficial impacts of repeated cultivations is essential.

\subsubsection{Plowing}

Plowing is an essential practice in C. arvense control, which has shown many significant results (for example, Pekrun and Claupein 2004; Melander et al. 2012). Melander et al. (2012) compared fall moldboard plowing (November) to spring moldboard plowing (March) and observed a nonsignificant greater efficacy for spring plowing in sandy soil. This difference was no longer seen when plowing was associated with repeated summer cultivations. Brandsæter et al. (2017) also showed a better reduction in $C$. arvense dry matter with late spring moldboard plowing (late April-May) than with fall plowing (October-November) in sandy loam and clay loam soils. Differences in efficacy between spring plowing and repeated cultivations between the two trials could be due to variations in the periods of spring plowing. Late plowing would be more efficient than early spring plowing, probably due to the greater sensitivity of $C$. arvense in late spring (see Section 2.2 and Table 1). The efficacy of spring plowing can also be increased by the highly competitive ability of spring crops, observed when spring crops are sown quickly after plowing, which can induce delayed emergence of $C$. arvense shoots (Thomsen et al. 2014).

Two trials experimented with a double-layer plowing that "combines a shallow inversion of the topsoil with a noninversive soil loosening of the subsoil by a goosefootshaped chisel, thus the natural soil stratification of the subsoil is maintained" (Gruber and Claupein 2009). Jasinskaite et al. (2009) observed an additional 25-34\% significant decrease in C. arvense density with double-layer plowing compared with that of moldboard plowing. Both plowings were performed at a $20-\mathrm{cm}$ depth. Gruber and Claupein (2009) found that double-layer plowing at a $25-\mathrm{cm}$ depth reduces $C$. arvense biomass significantly more than shallow plowing at a $15-\mathrm{cm}$ depth but had similar results to deep plowing $(25 \mathrm{~cm})$.

Deep ripping can be used by farmers to fragment $C$. arvense roots at a great depth, but no scientific data have been found with regard to the effect of deep ripping on the control of $C$. arvense or similar weeds.

\subsection{Effect of competition with cultivated species}

\subsubsection{Principles of competition for C. arvense control}

Competition for light limits the photosynthetic capacity of weeds and their development. There are different ways to limit C. arvense development and harmfulness: seeding of crops with significant soil cover, tall crops, and reduced row spacing. Competition for water and nutrients is linked to the characteristics of the root systems. $C$. arvense has a deep root system, which can reach a depth of 2 to $6.75 \mathrm{~m}$ (Rogers 1928; Hayden 1934; Moore 1975). This specificity gives it a competitive advantage over most cultivated species. The seeding of species with a deep root system can promote competition with $C$. arvense, as these crops can take up nutrients and water at a great depth where only $C$. arvense roots are present (Nadeau and Vanden Born 1989). Several cultural practices make use of these two types of competition on a different timescale, pluriannual or annual, during the cropping or intercropping period.

\subsubsection{Competitive pluriannual crops: alfalfa and temporary grasslands}

The main pluriannual crops used to control $C$. arvense are mown alfalfa (Medicago sativa) and temporary grasslands (Ominski et al. 1999; Verschwele and Häusler 2004; Melander et al. 2016). These crops combine the effects of (i) competition for light, through significant soil cover developing earlier than C. arvense in spring (Hodgson 1958) and regrowing quickly after mowing, and (ii) competition for access to water and nutrients through its deep root system (Rogers 1928). Moreover, mowing stimulates $C$. arvense regrowth, which leads to the mobilization of carbohydrates from its root reserves (Hodgson 1958). In comparison, in alfalfa grown for seed production, which is not mown, C. arvense is a troublesome weed (Mesbah and Miller 2005).

Mown alfalfa allows significant control of $C$. arvense (Hodgson 1958; Derscheid et al. 1961; Schreiber 1967; Ominski et al. 1999; Meiss et al. 2010). A significant efficacy of approximately $99 \%$ has been observed for 3-year alfalfa, mown twice a year, in a dry continental climate (Hodgson 1958). Similar results have been obtained for 4-year alfalfa, mown two to four times per year, in a humid continental climate (Schreiber 1967) and for 2-year temporary grasslands, mown twice, in an oceanic climate (Lukashyk et al. 2007). Based on these results, mown alfalfa efficacy does not appear to vary greatly with climate. Some studies-based on surveys - have determined that $C$. arvense control is enhanced in cropping systems that include 2- to 6-year-old alfalfa (Ominski et al. 1999; Meiss et al. 2010).

In arable crop rotations, the inclusion of forage crops can be difficult for farmers if there is no outlet for the production (Melander et al. 2016). More precise knowledge of the benefits of forage crops for $C$. arvense control could help determine the level of $C$. arvense infestation from which the introduction of pluriannual forage crops is beneficial even if these crops are considered cover crops.

The introduction of pluriannual forage crops is particularly beneficial, as no additional specific intervention is necessary since repeated mowing is needed to harvest alfalfa and temporary grasslands. Moreover, these cropping practices have a 
positive impact on soil fertility (Fernandez et al. 2017; Jarvis et al. 2017) unlike other nonchemical control practices, especially mechanical interventions (Thomsen et al. 2015; Melander et al. 2016).

\subsubsection{Competitive annual crops and cover crops to control $C$. arvense}

A few studies have focused on C. arvense control by competition with annual crops. C. arvense spreads in arable crops, particularly in crop rotations with a high proportion of cereals (Verschwele and Häusler 2004). Hodgson (1958) observed that spring wheat is not effective on its own at controlling C. arvense. Verschwele and Häusler (2004) highlighted that a high proportion of cereals and/or summer annual crops is present in the crop rotation of fields where $C$. arvense is problematic. Rasmussen (2011) noticed a slight nonsignificant and short-term beneficial effect of fiber hemp on $C$. arvense control due to its high competitive ability: no $C$. arvense was observed in the fall after the hemp harvest, but $C$. arvense plants reappeared in the next cropspring barley - at similar densities to that of fields with a different previous crop. Some studies have also tested the effect on $C$. arvense development of a 1-year fallow, based on grasses and leguminous mixtures. Graglia et al. (2006) reported a 69\% significant decrease in C. arvense biomass after a 16-month fallow, composed of white clover (Trifolium repens) and grass mixture. Thomsen et al. (2015) observed a $92 \%$ significant decrease in C. arvense biomass after a 16-month fallow, composed of timothy (Phleum pratense, $12.5 \mathrm{~kg} \mathrm{ha}^{-1}$ ), meadow fescue (Festuca pratensis, $7.5 \mathrm{~kg} \mathrm{ha}^{-1}$ ), red clover (Trifolium arvense, $3.75 \mathrm{~kg} \mathrm{ha}^{-1}$ ), and white clover (Trifolium repens, $1.25 \mathrm{~kg} \mathrm{ha}^{-1}$ ). Fertilization can favor crop growth and help the crop compete more effectively with $C$. arvense or, conversely, favor $C$. arvense development. Contradictory results have been observed: McIntyre and Hunter (1975) and Mamolos and Kalburtji (2001) found a positive significant effect of $\mathrm{N}$ fertilization on the competitive ability and development of $C$. arvense, while Melander et al. (2016) observed no impact of manure application on $C$. arvense. There have been more studies on the use of cover crops in $C$. arvense control. In several publications, cover crops are mown, making it hard to distinguish between the effect of cover crop competition and the effect of mowing. Moreover, it is necessary to separate allelopathic effects and physical inhibition by mulch. The results of known studies are presented in Table 2, which specifies the practices tested.

Most decreases in C. arvense have been observed for cover crops, including sudangrass (Bicksler and Masiunas 2009; Wedryk and Cardina 2012). Sudangrass can reach a substantial height of up to $3 \mathrm{~m}$ (Ngouajio et al. 2003 in Bicksler and
Masiunas 2009), much higher than C. arvense, which may explain its ability to compete with $C$. arvense. Cover crops with rapid development and a great ability for soil covering reduce $C$. arvense production of photoassimilates (Bicksler and Masiunas 2009; Wedryk and Cardina 2012). In contrast, buckwheat has a quick but short growth that induces the poor competitive ability this cover crop over $C$. arvense. Moreover, Eskelsen and Crabtree (1995) showed that there is only competition for light between $C$. arvense and buckwheat and no competition for access to water and nutrients because the species do not use the same resources.

The main decreases in C. arvense have been obtained for sowing dates in late spring (May or June, Bicksler and Masiunas 2009; Wedryk and Cardina 2012) when root reserves of $C$. arvense are low. Cover crops with summer development are generally more competitive (Teasdale et al. 2007; Bicksler and Masiunas 2009) because they reach their maximal growth at a period of low root reserves of $C$. arvense and prevent root reserves from being rebuilt.

The combination of planting competitive cover crops and repeated mowing can achieve better $C$. arvense control, but the species used have to be well adapted to repeated mowing, such as sudangrass, in contrast to buckwheat (Bicksler and Masiunas 2009). However, an additional effect due to mowing is not always observed despite important regrowth of the mown cover crop. Mowing and planting a cover crop show beneficial effects separately, but the effect of their combination is variable, which remains unexplained by Bicksler and Masiunas (2009). Tillage interventions previously applied to cover crop sowing could also impact $C$. arvense development, and cover crop destruction has an impact on $C$. arvense control because it is destroyed at the same time as the cover crop (Patriquin 1988 in Liebman and Dyck 1993).

Competition with cultivated species does not allow total control of $C$. arvense to be achieved. The main limit of this practice is that its efficacy does not last. When observations have continued for at least 1 year after crop or cover crop destruction, rapid and large increases in $C$. arvense have been observed. In some studies that compared the effect of competitive and noncompetitive crops on $C$. arvense, similar densities were noticed in all modalities 1 year after the end of the trial (Bicksler and Masiunas 2009; Rasmussen 2011). However, this practice can be combined, at the cropping system level, with mechanical interventions to improve $C$. arvense control. Combinations of competitive crops and cultural practices can achieve greater reductions in $C$. arvense: "The combined actions of green manure, deep burial and short roots therefore reduced the growth of C. arvense by $95-100 \%$, compared to $83-92 \%$ reduction by use of green manure alone, $26-37 \%$ by short roots alone, and $13-33 \%$ reduction by deep burial of roots alone." (Thomsen et al. 2011). 
Table 2 Efficacy of cover crop competition at controlling C. arvense by cover crop species, sowing modalities, number of mowing, and cover crop duration. Italicized data, beneficial effect; bold data, negative effect

\begin{tabular}{|c|c|c|c|c|c|c|}
\hline $\begin{array}{l}\text { Cover crop species } \\
\text { and their sowing } \\
\text { rates }\end{array}$ & $\begin{array}{l}\text { Previous crop } \\
\text { and sowing } \\
\text { modalities }\end{array}$ & $\begin{array}{l}\text { Number of } \\
\text { mowings }\end{array}$ & $\begin{array}{l}\text { Cover crop } \\
\text { duration }\end{array}$ & $\begin{array}{l}\text { Impact of various sowing dates } \\
\text { on } C \text {. arvense biomass }\end{array}$ & $\begin{array}{l}\text { Impact of cover crops on } C \text {. arvense } \\
\text { density and/or biomass }\end{array}$ & Sources \\
\hline $\begin{array}{l}\text { - Red clover } \\
\text { (Trifolium arvense): } \\
7-9 \mathrm{~kg} \mathrm{ha}^{-1} \\
\text { - Spring oats: } \\
200 \mathrm{~kg} \mathrm{ha}^{-1}\end{array}$ & $\begin{array}{l}\text { Sown in late } \\
\text { April - early } \\
\text { May }\end{array}$ & 0 & 3 months & - & $\begin{array}{l}\text { C. arvense density and biomass: no } \\
\text { significant effect }\end{array}$ & $\begin{array}{l}\text { Brandsæter } \\
\text { et al. } \\
2012\end{array}$ \\
\hline $\begin{array}{l}\text { - Oat (Avena sativa): } \\
54 \mathrm{~kg} \mathrm{ha}^{-1} \\
\text { - Field pea (Pisum } \\
\text { sativum): } \\
54 \mathrm{~kg} \mathrm{ha}^{-1} \\
\text { - Indian mustard } \\
\text { (Brassica juncea): } \\
6 \mathrm{~kg} \mathrm{ha}^{-1}\end{array}$ & $\begin{array}{l}\text { Sown after a red } \\
\text { clover } \\
\text { grassland } \\
\text { Test of } 3 \text { sowing } \\
\text { dates: } \\
\text { mid-May/late } \\
\text { May/early } \\
\text { June }\end{array}$ & 0 & 2.5 months & $\begin{array}{l}\text { Significant } 52-61 \% \text { decrease in } \\
\text { C. arvense biomass with } \\
\text { middle and late sowing dates, } \\
\text { in comparison with early } \\
\text { sowing date }\end{array}$ & - & $\begin{array}{l}\text { Wedryk } \\
\text { and } \\
\text { Cardina } \\
2012\end{array}$ \\
\hline $\begin{array}{l}\text { - Tef (Eragrostis tef): } \\
27 \mathrm{~kg} \mathrm{ha}^{-1} \\
\text { - Burr medic } \\
\text { (Medicago } \\
\text { polymorpha): } \\
8 \mathrm{~kg} \mathrm{ha}^{-1} \\
\text { - Buckwheat } \\
\text { (Fagopyrum } \\
\text { esculentum): } \\
25 \mathrm{~kg} \mathrm{ha}^{-1}\end{array}$ & $\begin{array}{l}\text { Sown after a red } \\
\text { clover } \\
\text { grassland } \\
\text { Test of } 3 \text { sowing } \\
\text { dates: } \\
\text { mid-May/late } \\
\text { May/early } \\
\text { June }\end{array}$ & 0 & 3-3.5 months & $\begin{array}{l}\text { Significant } 52-61 \% \text { decrease } \\
\text { with middle and late sowing } \\
\text { dates, in comparison with } \\
\text { early sowing date }\end{array}$ & - & $\begin{array}{l}\text { Wedryk } \\
\text { and } \\
\text { Cardina } \\
2012\end{array}$ \\
\hline $\begin{array}{l}\text { Buckwheat } \\
\text { (Fagopyrum } \\
\text { esculentum): } \\
101 \mathrm{~kg} \mathrm{ha}^{-1}\end{array}$ & $\begin{array}{l}\text { Sown after } \\
\text { temporary } \\
\text { grassland or } \\
\text { alfalfa } \\
\text { destruction, in } \\
\text { early June }\end{array}$ & $\begin{array}{l}\text { Test of } 3 \\
\text { modali- } \\
\text { ties: } \\
0 / 1 / 2\end{array}$ & 4 months & - & $\begin{array}{l}\text { C. arvense density and biomass: no } \\
\text { significant decrease }\end{array}$ & $\begin{array}{l}\text { Bicksler } \\
\text { and } \\
\text { Masiun- } \\
\text { as } 2009\end{array}$ \\
\hline $\begin{array}{l}\text { Sudangrass (Sorghum } \\
\text { sudanense): } \\
62 \mathrm{~kg} \mathrm{ha}^{-1}\end{array}$ & $\begin{array}{l}\text { Sown after } \\
\text { temporary } \\
\text { grassland or } \\
\text { alfalfa } \\
\text { destruction, in } \\
\text { early June }\end{array}$ & $\begin{array}{l}\text { Test of } 3 \\
\text { modali- } \\
\text { ties: } \\
0 / 1 / 2\end{array}$ & 4 months & - & $\begin{array}{l}\text { C. arvense density: significant } \\
90-95 \% \text { decrease } 1 \text { year after the } \\
\text { beginning of the trial. No more } \\
\text { effect } 15 \text { months after the } \\
\text { beginning of the trial. } \\
\text { C. arvense dry weight per shoot: large } \\
\text { decrease (40-60\%) }\end{array}$ & $\begin{array}{l}\text { Bicksler } \\
\text { and } \\
\text { Masiun- } \\
\text { as } 2009\end{array}$ \\
\hline $\begin{array}{l}\text { - Sudangrass } \\
\text { (Sorghum } \\
\text { sudanense): } \\
43 \mathrm{~kg} \mathrm{ha}^{-1} \\
\text { - Cowpea (Vigna } \\
\text { unguiculata): } \\
20 \mathrm{~kg} \mathrm{ha}^{-1}\end{array}$ & $\begin{array}{l}\text { Sown after } \\
\text { temporary } \\
\text { grassland or } \\
\text { alfalfa } \\
\text { destruction, in } \\
\text { early June }\end{array}$ & $\begin{array}{l}\text { Test of } 3 \\
\text { modali- } \\
\text { ties: } \\
0 / 1 / 2\end{array}$ & 4 months & - & $\begin{array}{l}\text { C. arvense density: significant } \\
\text { 90-95\% decrease } 1 \text { year after the } \\
\text { beginning of the trial. No more } \\
\text { effect } 15 \text { months after the } \\
\text { beginning of the trial. } \\
\text { C. arvense dry weight per shoot: } \\
\text { - Trial 1: } 200 \% \text { increase } \\
\text { - Trial 2: large decrease }\end{array}$ & $\begin{array}{l}\text { Bicksler } \\
\text { and } \\
\text { Masiun- } \\
\text { as } 2009\end{array}$ \\
\hline $\begin{array}{l}\text { - Sudangrass } \\
\text { (Sorghum } \\
\text { Sudanese) - } \\
\text { Sorghum (Sorghum } \\
\text { bicolor) mixture: } \\
25 \mathrm{~kg} \mathrm{ha}^{-1} \\
\text { - Inoculated soybean } \\
\text { (Glycine max): } \\
20 \mathrm{~kg} \mathrm{ha}^{-1} \\
\text { - Sunflower } \\
\text { (Helianthus } \\
\text { annuus): } 3 \mathrm{~kg} \mathrm{ha}^{-1}\end{array}$ & $\begin{array}{l}\text { Sown after a red } \\
\text { clover } \\
\text { grassland } \\
\text { Test of } 3 \text { sowing } \\
\text { dates: } \\
\text { mid-May/late } \\
\text { May/early } \\
\text { June }\end{array}$ & 0 & 3.5 months & $\begin{array}{l}\text { Significant } 52-61 \% \text { decrease } \\
\text { with the middle and late } \\
\text { sowing dates in comparison } \\
\text { with that of the early sowing } \\
\text { date }\end{array}$ & $\begin{array}{l}\text { C. arvense biomass: significant effect } \\
\text { of the cover crop }\end{array}$ & $\begin{array}{l}\text { Wedryk } \\
\text { and } \\
\text { Cardina } \\
2012\end{array}$ \\
\hline
\end{tabular}




\subsection{Effect of root extraction on C. arvense}

\subsubsection{Principles of root extraction}

Root extraction consists of the long-piece fragmentation and extraction of weed roots performed in dry and/or frozen weather conditions. Extracted roots can be left on the soil surface, exposed to direct sunlight or to desiccating winds to achieve their desiccation (Lötjönen and Vihonen 2014), or removed from the field. Specific implements have been developed to extract root fragments from the soil, including winged or goosefoot shares followed by a power take-off (PTO)-driven rotary cultivator (Lötjönen 2017). As a result of the passage of a PTO-driven rotary cultivator, soil and root fragments are thrown. As the root fragments are lighter than soil, they fall later and are placed on the soil surface, where they can desiccate or be picked up (Lötjönen and Vihonen 2014). The PTOdriven rotary cultivator gives the best results in light soils with low soil moisture. If these conditions are not met, root fragments may remain below the soil surface and can contribute to C. arvense multiplication.

\subsubsection{Methods using root extraction for $C$. arvense control}

Only a few studies deal with $C$. arvense root extraction. Brandsæter et al. (2012) observed that rotary tillage (by a Feraboli rotavator) carried out 10 to 14 days after wheat harvest in late summer achieved a significant decrease in $C$. arvense density of approximately $65-70 \%$, measured only in the following year, in both years of the experiment. Similar results were obtained in the same experiment with shallow plowing plus passes of an S-tine harrow (see Table 1). The $C$. arvense regrowth that was observed never reached the compensation point following the mechanical interventions.

The use of the Kvick-Finn cultivator, which is an implement specifically created for root extraction, has also been tested by Lötjönen (2017). Only 3\% of C. arvense remained alive after three passes of a Kvick-Finn cultivator in May and June followed by sowing of a cover crop. Similar results have been obtained after repeated stubble cultivations throughout the summer (see Table 1) (Brandsæter et al. 2012; Melander et al. 2012). The use of specific implements could allow bare fallow strategies, which provide great control of $C$. arvense, to be for shorter periods, but they have strong negative environmental and economic impacts. This practice could be carried out before sowing a summer crop to avoid suppressing the crop and to limit the economic impact.

According to the results of the experiments, root extraction could improve the efficacy of repeated cultivations (Lötjönen 2017). However, the efficacy of this practice largely depends on weather conditions in the months following treatment. Root extraction must be performed in desiccating and/or frosting conditions to allow the roots to dry and avoid $C$. arvense regrowth (Lötjönen and Vihonen 2014). Repeated harrowing after root extraction could help prevent $C$. arvense reimplantation to avoid its multiplication. However, this control method should not be implemented if the conditions for success are rarely met in the pedoclimatic conditions of the area.

\subsection{Other methods to control $C$. arvense}

Other control methods are outlined as follows. Knowledge of these methods is limited, but they could present new possibilities for future investigations.

\subsubsection{Solarization}

Solarization consists of "covering the soil with a transparent plastic sheeting during the appropriate period" (Katan and DeVay 1991). This treatment is applied directly to developing weeds. A significant effect of solarization on $C$. arvense control has been shown in two studies in Mediterranean and semiarid climates (Candido et al. 2011; Khan et al. 2012). Similar results were observed for all tested plastic films. Candido et al. (2011) showed that solarization maintained the soil temperature between 40 and $55^{\circ} \mathrm{C}$ at $10-\mathrm{cm}$ depth, but at greater depths, temperatures were more variable. In Khan et al. (2012), soil temperatures reached 45 to $52^{\circ} \mathrm{C}$ at 10 -cm depth. It can be assumed that solarization has an impact on $C$. arvense roots present at $10 \mathrm{~cm}$; however, as no measure of the depth of $C$. arvense roots has been carried out in these trials, it is not possible to say if solarization had an effect on deeper roots.

However, it would be necessary to test solarization in colder climates to verify whether the conditions for solarization efficiency can be achieved. In addition, solarization appears to stimulate the development of some other problematic weeds (Amaranthus deflexus, Amaranthus retroflexus, Vicia sativa, Melilotus sulcatus) (Candido et al. 2011; Khan et al. 2012), partly due to an increase in $\mathrm{N}$ availability (Khan et al. 2012).

\subsubsection{Biological control}

Biological control is the use of living agents to reduce the spread or vigor of weeds considered problematic (Blossey 2007; Lundkvist and Verwijst 2011). Many studies have been conducted on the biological control of $C$. arvense. Pathogens have been studied more than insects for $C$. arvense control, mainly in greenhouses (Lundkvist and Verwijst 2011; Orloff et al. 2018). According to these studies, the most effective agents on C. arvense are the pests Puccinia punctiformis and Sclerotinia sclerotiorum, along with the beetle Cassida rubiginosa (Orloff et al. 2018). Biological control has little effect on $C$. arvense development because the main biocontrol agents have an impact on its aerial parts, while the root 
reserves of $C$. arvense allow its regrowth after its aerial parts are suppressed (Evans 1984; Tiley 2010; Cripps et al. 2011). The combined use of several biological agents, such as folivores, agents causing stem damage, and agents provoking leaf necrosis, could improve the efficacy of biological control (Tiley 2010; Abela-Hofbauerova et al. 2011). Biological control can also be combined with mechanical practices, such as repeated cutting, to improve its efficacy (Kluth et al. 2003).

Biological agents must be used carefully because they can cause significant damage to nontarget species, native species, or crops (Evans 1984; Cripps et al. 2011). Many agents used for $C$. arvense control can also cause damage to native Cirsium species that only produce seeds. Furthermore, studies on the agents Cassida rubiginosa and Cleonus piger have been stopped in North America due to the risk of damage to artichoke (Cynara scolymus) (Cripps et al. 2011). The application of biocontrol agents in agricultural conditions highlights other issues related to the management of agent populations and their interactions with the local environment. For instance, agents must have limited mobility to ensure that they remain on the host plants (Evans 1984). Additionally, when the agents are imported organisms, they must be adapted to local climate conditions (Cripps et al. 2011). A biotic resistance or a predation relationship between the introduced agents and native species can also arise (Evans 1984; Cripps et al. 2011). All these parameters make biocontrol methods difficult to develop and explain why they are not currently used for $C$. arvense control.

\subsection{Combination of control practices impacting different biological processes}

As current methods have only a partial effect, the development of annual or multiyear strategies combining several methods would allow $C$. arvense control to be improved. Combined methods should include various biological processes for better efficacy (Bicksler and Masiunas 2009). The main combined biological processes are crop competition and weakening of root reserves (see Section 3.3). The most studied example is mown alfalfa, associating alfalfa competition and weakening of root reserves by repeated mowing (Hodgson 1958). Another example is the realization of repeated stubble cultivations in summer, which results in the weakening of root reserves, followed by sowing of a competitive cover crop (Lukashyk et al. 2007).

A more complex combination of biological processes has recently been studied (Lötjönen 2017). The trial consisted of repeated passes of a specific implement for root extraction in late spring (May and June), followed by sowing of a cover crop. In this study, the combined processes were competition, weakening, and root extraction associated with interventions at a key stage for $C$. arvense.
However, combinations of practices do not always result in a better effect than individual practices (i.e., mown sudangrass) (Bicksler and Masiunas 2009). Further research is necessary on which processes are relevant to combine. In addition, the combinations of practices already identified are all implemented at the scale of crop management routes: there has been no study of a multiyear strategy consisting of combinations of annual practices.

\section{Discussion}

Knowledge of $C$. arvense biology, in particular of the dynamics of root reserves throughout the year, has provided an explanation of the observed efficacies of various control methods and suggestions concerning some general rules for the implementation of these methods, for instance, the implementation of stubble cultivations at the compensation point. However, more research on $C$. arvense biology is needed to improve its control. The knowledge of $C$. arvense population dynamics, along with the impact of pedoclimatic conditions and their variations on the growth and development of $C$. arvense, is also necessary.

The impact of diverse factors, such as $C$. arvense population ecotypes, soil types, or climate, on the efficacy of practices is not well known. In addition, there is also a lack of knowledge about the impact of the $C$. arvense density on the efficacy of the control practices, whereas the most recent patches are known to have less competitive ability on crops (Mamolos and Kalburtji 2001), and the increase in patch size over time has been shown to be predictable (Eber and Brandl 2003). Furthermore, $C$. arvense development could increase as a consequence of climate change and increased $\mathrm{CO}_{2}$ levels (Hatcher and Froud-Williams 2017), even if Tørresen et al. (2019) reported contradictory results.

Current nonchemical C. arvense control in arable crops has mainly focused on its weakening by mechanical interventions (repeated cultivations to weaken the root reserves) and the introduction of mown forage crops in the rotation. Some $C$. arvense control methods are less studied, such as competition by using competitive crops and cover crops, deep cultivations, and root extraction. For these methods, studies on crop management routes are still required. Moreover, little is known about the duration of the efficacy of current $C$. arvense control methods and that of each control practice implemented over subsequent years. For practices involving a competition process, it is important to understand interactions with other cropping practices, such as fertilization or tillage interventions. For instance, fertilization could favor either the sown species, improving their competitive ability, or $C$. arvense development.

Farmers could face difficulties in implementing some $C$. arvense control methods described in this review. For 
instance, in northern regions, the time available for repeated cultivations in summer can be greatly reduced by the late harvest dates of cereals. Seeds can be difficult to find when specific species are advised (Bicksler and Masiunas 2009; Wedryk and Cardina 2012). The cost of cover crop seeds can also be problematic, especially if high sowing densities are necessary. However, seeds of cover crops can be reused from bulk grain produced on farms, and EU farmers can also use specific funds from the Common Agricultural Policy for agroenvironmental measures. The cost of specific implements can also limit the practical application of some $C$. arvense control methods, such as root extraction. Collective investment could be developed to help farmers purchase these implements, and other uses could also be developed for them. It would also be useful to know if more usual implements can achieve similar results to verify whether specific investment is truly necessary.

C. arvense control methods can have negative environmental, social, and economic impacts (Melander et al. 2016). Repeated mechanical interventions, which are the most studied practices for $C$. arvense control, involve high fuel consumption and greenhouse gas emissions and take up a great deal of working time for farmers (Lötjönen and Vihonen 2014). Cultivations made in the summer can disturb cover crop implantation and significantly reduce their growth if the last cultivations induce a late sowing date (Lawson et al. 2015), which could have a negative impact on cover crop services to the agrosystem. Repeated cultivations are also contradictory to no-till systems that are developing all over the world for the management of long-term soil fertility and for economic reasons. Mowing and hoeing have a less negative environmental impact but are also less effective unless they are associated with competitive crops (i.e., alfalfa). Further studies are needed to establish whether the root extraction method could reduce the high negative impacts of $C$. arvense control. The use of competitive crops and cover crops as control methods can have a positive impact on soil fertility, in contrast to cultivations, and improve nutrient managementthus avoiding nutrient leaching (Constantin et al. 2010; Haruna and Nkongolo 2015)_but current knowledge on these practices is limited.

In summary, the direct and indirect impacts of each control method should be studied in relation to its benefits at annual and cropping system scales to limit their negative impacts and to help farmers choose the control practices best adapted to their situations. For instance, the cultivation time schedule should be given some thought depending on the following crop; cultivations should preferentially be planned during the intercrops to allow the implementation of control methods at sensitive stages of $C$. arvense, in particular at the appearance of flower buds, in order to optimize their efficacy, and before winter crops, in order to not disturb cover crop implantation before summer crops. Furthermore, when $C$. arvense patches are conveniently located, $C$. arvense control on a local scale, with spatial modulations of practices in the field, could be conceivable.

There is a lack of knowledge to enable the implementation of combinations of different control methods, on an annual or multiyear scale, across arable cropping systems. The interactive effects between control practices, as well as the interactions between biological processes, are largely unknown. Knowledge of the duration of the efficacy of the practices would be needed to plan the frequency of implementation of the control methods and combine them in cropping systems. Knowledge of these nonchemical control methods of $C$. arvense could also be used to combine them with conventional control methods to provide efficient mixed strategies, as shown by Miller (2016).

The adaptation of $C$. arvense control methods to local conditions also presents a challenge. New methods for producing innovations, such as the codesign of farming systems involving researchers and farmers, can allow the design of multiyear strategies for pest management fitted to a specific context (Meynard et al. 2012; Petit et al. 2012; Lefèvre et al. 2014) and could be applied to $C$. arvense control. The study of the practices and strategies of innovative farmers can also be a source of solutions. Working methods such as tracking onfarm innovations (Lamé et al. 2015; Salembier et al. 2016; Salembier 2019) could highlight alternative methods and multiyear strategies developed by farmers.

Although additional knowledge is still needed on $C$. arvense control, this is one of the best-known perennial weeds. Similarities in the biological characteristics of $C$. arvense and other perennial weeds (i.e., Convolvulus arvensis) could provide the basis for identifying potential new control methods for these weeds. Moreover, research often focuses on the control of some specific weeds, whereas mixed stands of weeds are often present in fields. Thus, it is important to integrate $C$. arvense control strategies into more comprehensive thinking (Melander et al. 2012, 2016) and undertake more research on the simultaneous control of various weed species. The functional traits approach developed by Gaba et al. (2017) could be interesting in this prospect.

\section{Conclusions}

The efficiency of some $C$. arvense control methods is already known; for instance, the implementation of repeated stubble cultivations in summer and the introduction of mown alfalfa have been shown to be significantly efficient. However, little is known about the long-term efficacy of these control methods and about other more exploratory control methods. This review confirms that one individual practice, implemented in 1 year only, is not sufficient to provide satisfactory control of $C$. arvense in the long term, and therefore, 
combinations of control strategies are required. However, knowledge about the implementation of such combinations of control methods in multiyear strategies is limited, and further studies on interactions, complementarities, and synergies between control methods of $C$. arvense are necessary. Further research is also needed to limit the negative environmental, social, and economic impacts of $C$. arvense control methods.

To guarantee the efficiency of these control practices, knowledge of $C$. arvense biology is essential. This review synthesizes the key points from the previous literature on $C$. arvense biology that can be mobilized to this end. In particular, we propose a conceptual model of the evolution during the year of the thistle root reserves, which makes it possible to understand the diversity of the effects of the same practice, according to its date, and opens tracks for research on the combinations of control methods.

C. arvense is one of the best-known perennial weeds, but other perennial and annual weeds are also problematic. Different means of control are used on annual and perennial weeds, and their effects are sometimes antagonistic. For instance, stubble cultivations are not implemented at the same frequency if their goal is to weaken the root reserves of perennial weeds or decrease the soil seed bank of annual weeds. In cropping systems that do not use herbicides or use them only as a last resort, rotations, tillage, sowing, and mowing dates must be scheduled according to the whole flora to be controlled and not only one species. Research is therefore required on the control of mixed stands of perennial and annual weeds to build global strategies for weed control. These investigations are essential because herbicide regulations are rapidly evolving.

Authors' contribution Collection and analysis of the corpus: E.F., A.R., J.P. Original draft: E.F. Writing — review and editing: E.F., A.R., J.M.M. Funding acquisition and resources: J.P. Scientific supervision: J.M.M.

\section{Compliance with ethical standards}

Conflict of interest The authors declare that they have no conflict of interest.

\section{References}

Abela-Hofbauerova I, Münzbergova Z, Skuhrovec J (2011) The effect of different natural enemies on the performance of Cirsium arvense in its native range. Weed Res 51:394-340. https://doi.org/10.1111/j. 1365-3180.2011.00851.x

Andersson L, Boström U, Forkman J, Hakman I, Liew J, Magnuski E (2013) Sprouting capacity form intact root systems of Cirsium arvense and Sonchus arvensis decrease in autumn. Weed Res 53: 183-119. https://doi.org/10.1111/wre.12013

Bakker D (1960) A comparative life-history study of Cirsium arvense (L.) Scop. and Tussilago farfara (L.), the most troublesome weeds in the newly reclaimed polders of the former Zuiderzee. In Biology of weeds, Symp. Brit. Ecol. Soc., pp. 205-222
Bicksler AJ, Masiunas JB (2009) Canada thistle (Cirsium arvense) suppression with buckwheat or sudangrass cover crops and mowing. Weed Technol 23(4):556-556. https://doi.org/10.1614/WT-09-050.

Blossey B (2007) Biological control of weeds using arthropods. In: Nonchemical weed management: principles, concepts and technology. CABI, Cambridge, pp. 77-92. doi: https://doi.org/10.1079/ 9781845932909.0000

Blumenthal D, Jordan N (2001) Weeds in field margins: a spatially explicit simulation analysis of Canada thistle population dynamics. Weed Sci 49(4):509-519. https://doi.org/10.1614/00431745(2001)049[0509:WIFMAS]2.0.CO;2

Bommarco R, Lönn M, Danzer U, Pålsson KJ, Torstensson P (2010) Genetic and phenotypic differences between thistle populations in response to habitat and weed management practices. Biol J Linn Soc 99(4):797-807. https://doi.org/10.1111/j.1095-8312.2010.01399.x

Bond W, Grundy AC (2001) Non-chemical weed management in organic farming systems. Weed Res 41(5):383-405. https://doi.org/10.1046/ j.1365-3180.2001.00246.x

Borochov A, Spiegelstein H, Weiss D (1997) Dormancy and storage of geophytes. Acta Horticulturae 430:405-410. https://doi.org/10. 17660/ActaHortic.1997.430.65

Brandsæter LO, Fogelfors H, Fykse H, Graglia E, Jensen RK, Melander B, Salonen J, Vanhala P (2010) Seasonal restrictions of bud growth on roots of Cirsium arvense and Sonchus arvensis and rhizomes of Elymus repens. Weed Res 50:102-109. https://doi.org/10.1111/j. 1365-3180.2009.00756.x

Brandsæter LO, Thomsen MG, Waernhus K, Fykse H (2012) Effects of repeated clover undersowing in spring cereals, and stubble treatments in autumn on Elymus repens, Sonchus arvensis and Cirsium arvense. Crop Prot 32:104-110. https://doi.org/10.1016/j.cropro. 2011.09.022

Brandsæter LO, Mangerud K, Helgheim M, Berge TW (2017) Control of perennial weeds in spring cereals through stubble cultivation and mouldboard ploughing during autumn or spring. Crop Prot 98:1623. https://doi.org/10.1016/j.cropro.2017.03.006

Buhler DD, Liebman M, Obrycki JJ (2000) Theoretical and practical challenges to an IPM approach to weed management. Weed Science 48(3):274-280. doi:https://doi.org/10.1614/00431745(2000)048[0274:tapcta] 2.0.co;2

Candido V, D'Addabbo T, Miccolis V, Castronuovo D (2011) Weed control and yield response of soil solarization with different plastic films in lettuce. Sci Hortic 130(3):491-497. https://doi.org/10.1016/ j.scienta.2011.08.002

Christoffoleti PJ, Carvalho SJP, Nicolai M, Doohan D, VanGessel M (2007) Prevention strategies in weed management. In: Nonchemical weed management: principles, concepts and technology. CABI, Oxfordshire, pp 1-16. https://doi.org/10.1079/ 9781845932909.0000

Constantin J, Beaudoin N, Laurent F, Cohan J-P, Duyme F, Mary B (2010) Cumulative effects of catch crops on nitrogen uptake, leaching and net mineralization. Plant Soil 341(1-2):137-154. https://doi.org/10.1007/s11104-010-0630-9

Cox HR (1913) Controlling Canada thistles. US Department of Agriculture

Cripps MG, Gassmann A, Fowler SV, Bourdôt GW, McClay AS, Edwards GR (2011) Classical biological control of Cirsium arvense: lessons from the past. Biol Control 57(3):165-174. https://doi.org/ 10.1016/j.biocontrol.2011.03.011

Cripps MG, Dowsett CA, Jackman SD, Van Koten C, Goeke DF, Houliston GJ (2020) Genetic variation in tolerance to defoliation in Cirsium arvense. Weed Res 60(1):78-84. https://doi.org/10. $1111 /$ wre. 12391

Davis S, Mangold J, Menalled F, Orloff N, Miller Z, LehnhoffE (2018) A meta-analysis of Canada thistle (Cirsium arvense) management. Weed Sci 66(4):548-557. https://doi.org/10.1017/wsc.2018.6 
Derscheid LA, Nash RL, Wicks GA (1961) Thistle control with cultivation, cropping and chemicals. Weeds 9(1):90-102. https://doi.org/ $10.2307 / 4040390$

Detmers F (1927) Canada thistle, Cirsium arvense Tourn Ohio Agricultural Experiment Station Bulletin 414. https://kb.osu.edu/ bitstream/handle/1811/60849/1/OARDC_bulletin_n414.pdf

Dock Gustavsson A-M (1997) Growth and regenerative capacity of plants of Cirsium arvense. Weed Res 37(4):229-236. https://doi. org/10.1046/j.1365-3180.1997.d01-37.x

Donald WW (1990) Management and control of Canada thistle (Cirsium arvense). Reviews of weed Science 5:193-249

Eber S, Brandl R (2003) Regional patch dynamics of Cirsium arvense and possible implications for plant-animal interactions. J Veg Sci 14(2):259-266. https://doi.org/10.1658/1100-9233(2003)014[0259: RPDOCA]2.0.CO;2

Eskelsen SR, Crabtree GD (1995) The role of allelopathy in buckwheat (Fagopyrum sagittatum) inhibition of Canada thistle (Cirsium arvense). Weed Sci 43(1):70-74. https://doi.org/10.1017/ S004317450008084X

Evans JE (1984) Canada thistle (Cirsium arvense): a literature review of management practices. Nat Areas J 4(2):11-21

Fernandez AL, Fabrizzi KP, Tautges NE, Lamb JA, Sheaffer CC (2017) Cutting management and alfalfa stand age effects on organically grown corn grain yield and soil $\mathrm{N}$ availability. Renewable Agriculture and Food Systems 34(2):1-11. https://doi.org/10.1017/ s1742170517000394

Gaba S, Perronne R, Fried G, Gardarin A, Bretagnolle F, Biju-Duval L, Reboud X (2017) Response and effect traits of arable weeds in agroecosystems: a review of current knowledge. Weed Res 57(3):123147. https://doi.org/10.1111/wre.12245

Glemnitz M, Radics L, Mackensen K (2007) Weed management in organic farming in the new EU member states and the acceding countries - status quo and main limitations. 3rd QLIF Congress, Hohenheim, Germany, 20-23 March 2007

Golubinova I, Ilieva A (2015) Allelopathic effects of water extracts of Sorghum halepense (L.) Pers., Convolvulus arvensis L. and Cirsium arvense Scop. on early seedling growth of some leguminous crops. Pestic. Phytomed. (Belgrade) 29(1):35-43. https://doi.org/10.2298/ PIF1401035G

Graglia E, Melander B, Jensen RK (2006) Mechanical and cultural strategies to control Cirsium arvense in organic arable cropping systems. Weed Res 46:304-312. https://doi.org/10.1111/j.1365-3180.2006. 00514.x

Gruber S, Claupein W (2009) Effect of tillage intensity on weed infestation in organic farming. Soil Tillage Res 105:104-111. https://doi. org/10.1016/j.still.2009.06.001

Håkansson S (1982) Multiplication, growth and persistence of perennial weeds. In: Biology and ecology of weeds. Springer, Dordrecht, pp.123-135. doi: https://doi.org/10.1007/978-94-017-0916-3

Håkansson S (2003) Weeds and weed management on arable land: an ecological approach. CABI Publishing. https://doi.org/10.1079/ 9780851996516.0000

Hamdoun AM (1972) Regenerative capacity of root fragments of Cirsium arvense (L.) Scop. Weed Res 12:128-136. https://doi.org/10.1111/j. 1365-3180.1972.tb01196.x

Haruna SI, Nkongolo NV (2015) Effects of tillage, rotation and cover crop on the physical properties of a silt-loam soil. International Agrophysics 29(2):137-145. https://doi.org/10.1515/intag-20150030

Hatcher PE, Froud-Williams RJ (2017) Perennial weeds. In: Weed research: expanding horizons. John Wiley et Sons, pp. 389-412. doi: https://doi.org/10.1002/9781119380702

Hayden A (1934) Distribution and reproduction of Canada thistle in Iowa. Am J Bot 21(7):355-373. https://doi.org/10.1002/j.15372197.1934.tb04968.x
Heimann B, Cussans GW (1996) The importance of seeds and sexual reproduction in the population biology of Cirsium arvense - a literature review. Weed Res 36:493-503. https://doi.org/10.1111/j. 1365-3180.1996.tb01678.x

Hettwer U, Gerowitt B (2004) An investigation of genetic variation in Cirsium arvense field patches. Weed Res 44:289-297. https://doi. org/10.1111/j.1365-3180.2004.00402.x

Hodgson JM (1958) Canada thistle (Cirsium arvense Scop.) control with cultivation, cropping, and chemical sprays. Weeds 6(1):1-11. https://doi.org/10.2307/4040301

Hodgson JM (1968) The nature, ecology, and control of Canada thistle. Technical bulletin 1386. US Department of Agriculture. https:// ageconsearch.umn.edu/record/171614/files/tb1386.pdf

Hodgson JM (1970) The response of Canada thistle ecotypes to 2,4-D, amitrole, and intensive cultivation. Weed Sci 18(2):253-255. https:// doi.org/10.1017/S0043174500079686

Jarvis N, Forkman J, Koestel J, Kätterer T, Larsbo M, Taylor A (2017) Long-term effects of grass-clover leys on the structure of a silt loam soil in a cold climate. Agric Ecosyst Environ 247:319-328. https:// doi.org/10.1016/j.agee.2017.06.042

Jasinskaite S, Pilipavicius V, Lazauskas P (2009) Perennial weed control by two layer ploughing. Agronomy Research 7(Special issue I): 277-282 doi: 20.500.12259/81796

Katan J, DeVay JE (1991) Soil solarization. cRC Press

Khan MA, Marwat KB, Amin A, Nawaz A, Khan R, Khan H, Shah HU (2012) Soil solarization: an organic weed-management approach in cauliflower. Commun Soil Sci Plant Anal 43(13):1847-1860. https://doi.org/10.1080/00103624.2012.684822

Kluth S, Kruess A, Tscharntke T (2003) Influence of mechanical cutting and pathogen application on the performance and nutrient storage of Cirsium arvense. J Appl Ecol 40(2):334-343. https://doi.org/10. 1046/j.1365-2664.2003.00807.x

Lalonde RG, Roitberg BD (1994) Mating system, life-history, and reproduction in Canada thistle (Cirsium arvense (Asteraceae)). Am J Bot 81(1):21-28. https://doi.org/10.1002/j.1537-2197.1994.tb15404.x

Lamé A, Jeuffroy MH, Pelzer E, Meynard JM (2015) Les agriculteurs sources d'innovations: exemple des associations pluri-spécifiques dans le grand Ouest de la France. Agronomie Environnement et Société 5:47-54 https://agronomie.asso.fr/fileadmin/user upload/ Revue_AES/AES_vo15_n2_dec2015/AES_vol5_n2_pdf/AES vol5 n2 09 Lame et al.pdf

Lawson A, Cogger C, Bary A, Fortuna A-M (2015) Influence of seeding ratio, planting date, and termination date on rye-hairy vetch cover crop mixture performance under organic management. PLoS One 10(6):e0129597. https://doi.org/10.1371/journal.pone.0129597

Lefèvre V, Capitaine M, Peigné J, Roger-Estrade J (2014) Farmers and agronomists design new biological agricultural practices for organic cropping systems in France. Agron Sustain Dev 34(3):623-632. https://doi.org/10.1007/s13593-013-0177-2

Liebman M (2001) Ecological management of agricultural weeds. Cambridge University Press. https://doi.org/10.1017/ CBO9780511541810

Liebman M, Dyck E (1993) Crop rotation and intercropping strategies for weed management. Ecol Appl 3(1):92-122. https://doi.org/10.2307/ 1941795

Liebman M, Davis AS, Francis C (2009) Managing weeds in organic farming systems: an ecological approach. Organic Farming: the Ecological System. https://doi.org/10.2134/agronmonogr54.c8

Liew J, Andersson L, Boström U, Forkman J, Hakman I, Magnuski E (2012) Influence of temperature and photoperiod on sprouting capacity of Cirsium arvense and Sonchus arvensis root buds. Weed Res 52(5):449-457. https://doi.org/10.1111/j.1365-3180.2012. 00936.x

Lötjönen T (2017) Efficiency of different bare fallow strategies to control perennial weeds. In: NJF Seminar 495- 4th organic conference: organics for tomorrow's food systems, 19-21 June 2017, Mikkeli, 
Finland (Vol. 13, No. 1, pp. 54-55). http://njf.nu/assets/Uploads/ NJF-proceedings.pdf\#page $=56$

Lötjönen T, Vihonen E (2014) Mechanical control of Elymus repensfarm tests. In: NJF Seminar 471:8 http://njf.is/assets/Uploads/NJFReport-vol-10-no-1-2014.pdf\#page $=8$

Lukashyk P, Berg M, Köpke U (2007) Strategies to control Canada thistle (Cirsium arvense) under organic farming conditions. Renewable Agriculture and Food Systems 23(1):13-18. https://doi.org/10. 1017/S1742170507002013

Lundkvist A, Verwijst T (2011) Weed biology and weed management in organic farming. In: Research in Organic Farming IntechOpen. https://doi.org/10.5772/2441

Mamolos AP, Kalburtji KL (2001) Competition between Canada thistle and winter wheat. Weed Sci 49(6):755-759. https://doi.org/10. 1614/0043-1745(2001)049[0755:CBCTAW]2.0.CO;2

McAllister RS, Haderlie LC (1985) Seasonal variations in Canada thistle (Cirsium arvense) root bud growth and root carbohydrate reserves. Weed Sci 33(1):44-49. https://doi.org/10.1017/ S0043174500083909

Mcintyre GI, Hunter JH (1975) Some effects of the nitrogen supply on growth and development of Cirsium arvense. Canadian Journal of Botanic 53:3012-3021. https://doi.org/10.1139/b75-330

Meiss H, Médiène S, Waldhardt R, Caneill J, Bretagnolle V, Reboud X, Munier-Jolain N (2010) Perennial alfalfa affects weed community trajectories in grain crop rotations. Weed Res 50:331-340. https:// doi.org/10.1111/j.1365-3180.2010.00784.x

Melander B, Holst N, Rasmussen IA, Hansen PK (2012) Direct control of perennial weeds between crops - implications for organic farming. Crop Prot 40:36-42. https://doi.org/10.1016/j.cropro.2012.04.029

Melander B, Rasmussen IA, Olesen JE (2016) Incompatibility between fertility building measures and the management of perennial weeds in organic cropping systems. Agric Ecosyst Environ 220:184-192. https://doi.org/10.1016/j.agee.2016.01.016

Mesbah AO, Miller SD (2005) Canada thistle (Cirsium arvense) control in established alfalfa (Medicago sativa) grown for seed production. Weed Technol 19(4):1025-1029. https://doi.org/10.1614/WT-05032R.1

Meynard JM, Dedieu B, Bos AP (Bram) (2012) Re-design and co-design of farming systems. An overview of methods and practices. In: Farming systems research into the 21st century: the new dynamic. Springer, Dordrecht, pp. 405-429. doi: https://doi.org/10.1007/97894-007-4503-2

Miller TW (2016) Integrated strategies for management of perennial weeds. Invasive Plant Science and Management 9(2):148-158. https://doi.org/10.1614/IPSM-D-15-00037.1

Moore RJ (1975) The biology of Canadian weeds. 13, Cirsium arvense (L) Scop. Can J Plant Sci 55:1033-1048. https://doi.org/10.4141/ cjps $75-163$

Nadeau LB, Vanden Born WH (1989) The root system of Canada thistle. Can J Plant Sci 69:1199-1206. https://doi.org/10.4141/cjps89-142

Nkurunziza L (2010) Phenology and source sink dynamics of carbohydrates in relation to management of perennial weeds Cirsium arvense and Tussilago farfara. $\mathrm{PhD}$ dissertation, University of Copenhagen, Agriculture and Ecology. https://orgprints.org/18240/ 1/18240.pdf

Nkurunziza L, Streibig JC (2011) Carbohydrate dynamics in roots and rhizomes of Cirsium arvense and Tussilago farfara. Weed Res 51(5):461-468. https://doi.org/10.1111/j.1365-3180.2011.00866.x

Ngouajio M, McGiffen M, Hutchinson CM (2003) Effect of cover crop and management system on weed populations in lettuce. Crop Prot. 22:57-64

Nobarinezhad MH, Challagundla L, Wallace LE (2020) Small-scale population connectivity and genetic structure in Canada thistle (Cirsium arvense). Int J Plant Sci 181(4):473-484. https://doi.org/10.1086/ 706882
Ominski PD, Entz MK, Kenkel N (1999) Weed suppression by Medicago sativa in subsequent cereal crops: a comparative survey. Weed Sci 47:282-290. https://doi.org/10.1017/S0043174500091785

Orloff N, Mangold J, Miller Z, Menalled F (2018) A meta-analysis of field bindweed (Convolvulus arvensis L.) and Canada thistle (Cirsium arvense L.) management in organic agricultural systems. Agric Ecosyst Environ 254:264-272. https://doi.org/10.1016/j.agee. 2017.11.024

O'Sullivan PA, Kossatz VC, Weiss GM, Dew DA (1982) An approach to estimating yield loss of barley due to Canada thistle. Can J Plant Sci 62:125-731. https://doi.org/10.4141/cjps82-105

O'Sullivan PA, Weiss GM, Kossatz VC (1985) Indices of competition for estimating rapeseed yield loss due to Canada thistle. Can J Plant Sci 65:145-149. https://doi.org/10.4141/cjps85-020

Otzen D, Koridon AH (1970) Seasonal fluctuations of organic food reserves in underground parts of Cirsium arvense (L) Scop and Tussilago farfara L. Acta Bot Neerl 19(4):502. https://doi.org/10. 1111/j.1438-8677.1970.tb00675.x

Patriquin DG, Hill NM, Baines D, Bishop M, Allen G (1986) Observations on a mixed farm during the transition to biological husbandry. Biological Agriculture \& Horticulture 4(2):69-154. https://doi.org/10.1080/01448765.1986.9754491

Patriquin DG (1988) Weed control in organic farming systems. In: Weed management in agroecosystems: ecological approaches, CRC Press, pp. 303-317.

Pekrun C, Claupein W (2004) The effect of stubble tillage and primary tillage for weed population dynamics of Canada thistle (Cirsium arvense) in organic farming. Journal of Plant Diseases and Protection Special Issue XIX:483-490. https://doi.org/10.1016/j. still.2009.06.001

Petit MS, Reau R, Dumas M, Moraine M, Omon B, Josse S (2012) Mise au point de systèmes de culture innovants par un réseau d'agriculteurs et production de ressources pour le conseil. Innovations Agronomiques 20:79-100 https://prodinra.inra.fr/ft? $\mathrm{id}=\{105223 \mathrm{~A} 2-929 \mathrm{~B}-48 \mathrm{~B} 4-\mathrm{A} 481-2061274689 \mathrm{FA}\} \&$ original=true

Pilipavičius V, Romaneckas K (2014) Allelopathic activity of creeping thistle water extracts on germination and early growth of winter wheat. Bulgarian Journal of Agricultural Science 20(3):607-612 doi: $20.500 .12259 / 87144$

Rasmussen IA (2011) Use of competitive crops to reduce Cirsium arvense. In: Organic is life-knowledge for tomorrow. Proceedings of the 3rd Scientific Conference of the International society of organic agriculture research 1, pp. 692-695. https://orgprints.org/ 19571/

Riesinger P, Hyvönen T (2006) Impact of management on weed species composition in organically cropped spring cereals. Biological Agriculture \& Horticulture 24(3):257-274. https://doi.org/10.1080/ 01448765.2006.9755025

Rodriguez A, Prieur L, Laffont L, Prud'homme M. (2007) Carbohydrates flow of Canada thistle (Cirsium arvense (L.) Scop.) under mechanical control and practical results. In: Proceedings of the XXth International Conference on Weed Biology, Dijon, France, 276288. Association Française pour la Protection des Plantes (AFPP), Paris, France

Rogers CF (1928) Canada thistle and Russian knapweed and their control. Colorado Agricultural Experiment Station. Bulletin 348. https:// pdfs.semanticscholar.org/2447/7ade 7 e 852 d840ff1b2aa4db c8083b4864220.pdf

Sagar GR, Rawson HM (1964) The biology of Cirsium arvense (L.) Scop. In: Proceedings of the 7th British Weed Control Conference. Brighton, UK, pp. 553-56. doi: https://doi.org/10.13140/2.1.4818. 3049

Salembier C (2019) Stimuler la conception distribuée de systèmes agroécologiques par l'étude de pratiques innovantes d'agriculteurs. $\mathrm{PhD}$ Dissertation, French University of Paris Saclay and AgroParis Tech. https://tel.archives-ouvertes.fr/tel-02305973/document 
Salembier C, Elverdin JH, Meynard JM (2016) Tracking on-farm innovations to unearth alternatives to the dominant soybean-based system in the Argentinean Pampa. Agron Sustain Dev 36(1):1. https:// doi.org/10.1007/s13593-015-0343-9

Schreiber MM (1967) Effect of density and control of Canada thistle on production and utilisation of alfalfa pasture. Weed Sci 15(2):138 142. https://doi.org/10.2307/4041184

Schroeder D, Mueller-Schaerer H, Stinson CSA (1993) A European weed survey in 10 major crop systems to identify targets for biological control. Weed Res 33:449-458. https://doi.org/10.1111/j.13653180.1993.tb01961.x

Tavaziva VJ (2017) Effects of integrated pest management (IPM) on the population dynamics of the perennial weed species Cirsium arvense (L.) Scop. PhD Dissertation, Swedish University of Uppsala. https:// pub.epsilon.slu.se/14765/

Tavaziva VJ, Lundkvist A, Verwijst T (2019) Effects of selective cutting and timing of herbicide application on growth and development of Cirsium arvense in spring barley. Weed Res 59(5):349-356. https:// doi.org/10.1111/wre.12371

Teasdale JR, Brandsaeter LO, Calegari A, Skora Neto F (2007) 4 cover crops and weed management. In: Non-chemical weed management: principles, concepts and technology. Eds MK Upadhyaya, RE Blackshaw. CABI, pp. 49-64. doi: https://doi.org/10.1079/ 9781845932909.0000

Thomsen MG, Brandsæter LO, Fykse H (2011) Sensitivity of Cirsium arvense to simulated tillage and competition. Acta Agriculturae Scandinavica, Section B-Soil \& Plant Science 61(8):693-700. https://doi.org/10.1080/09064710.2010.543142

Thomsen MG, Brandsæter LO, Fykse H (2014) Regrowth of Cirsium arvense from intact roots and root fragments at different soil depths. Julius-Kühn-Archiv 443:234. https://doi.org/10.5073/jka.2014.443. 028

Thomsen MG, Mangerud K, Riley H, Brandsæter LO (2015) Method, timing and duration of bare fallow for the control of Cirsium arvense and other creeping perennials. Crop Prot 77:31-37. https://doi.org/ $10.1016 /$ j.cropro.2015.05.020

Tiley GE (2010) Biological flora of the British Isles: Cirsium arvense (L.) Scop. J Ecol 98(4):938-983. https://doi.org/10.1111/j.1365-2745. 2010.01678.x

Tørresen KS, Fykse H, Rafoss T, Gerowitt B (2019) Autumn growth of three perennial weeds at high latitude benefits from climate change.
Glob Chang Biol 26(4):2561-2572. https://doi.org/10.1111/gcb. 14976

Tworkoski T (1992) Developmental and environmental effects on assimilate partitioning in Canada thistle (Cirsium arvense). Weed Sci 40(1):79-85. https://doi.org/10.1017/S004317450005699X

Verschwele A, Häusler A (2004) Effect of crop rotation and tillage on infestation of Cirsium arvense in organic farming systems. 6th EWRS Workshop on Physical and Cultural Weed Control, Lillehammer, Norway, pp. 187-194. http://citeseerx.ist.psu.edu/ viewdoc/download?doi=10.1.1.622.7735\&rep= rep1\&type $=$ pdf\# page $=194$

Verwijst T, Tavaziva VJ, Lundkvist A (2017) Effects of selective cutting and herbicide use in spring barley on seed production of Cirsium arvense. Acta Agriculturae Scandinavica, Section B - Soil \& Plant Science 67(6):562-570. https://doi.org/10.1080/09064710.2017. 1318164

Verwijst T, Tavaziva VJ, Lundkvist A (2018) Assessment of the compensation point of Cirsium arvense and effects of competition, root weight and burial depth on below-ground dry weight - leaf stage trajectories. Weed Res 58(4):292-303. https://doi.org/10.1111/wre. 12312

Wedryk S, Cardina J (2012) Smother crop mixtures for Canada thistle (Cirsium arvense) suppression in organic transition. Weed Sci 60: 618-623. https://doi.org/10.1614/WS-D-11-00140.1

Welton FA, Morris VH, Hartzler AJ (1929) Organic food reserves in relation to the eradication of Canada thistles. Ohio agricultural experiment station Bulletin 441. https://kb.osu.edu/handle/1811/ 60879

Westwood JH, Charudattan R, Duke SO, Fennimore SA, Marrone P, Slaughter DC, Swanton C, Zollinger R (2018) Weed management in 2050: perspectives on the future of weed science. Weed Sci 66(03):275-285. https://doi.org/10.1017/wsc.2017.78

Wilson RG (1979) Germination and seedling development of Canada thistle (Cirsium arvense). Weed Sci 27(2):146-151. https://doi.org/ $10.1017 / \mathrm{S} 0043174500043708$

Publisher's note Springer Nature remains neutral with regard to jurisdictional claims in published maps and institutional affiliations. 